\title{
High-strength Concrete with Natural Aggregates, Silica Fume, and Polypropylene Macrofibers*
}

\author{
Ramón Torres-Ortega - Edgar Quiñonez-Bolaños ${ }^{\mathrm{b}}$ - Candelaria Tejada-Tovar \\ - Yineth García-Díaz ${ }^{d}$ Ibeth Cabarcas-Torres ${ }^{\mathrm{e}}$
}

\begin{abstract}
The use of concrete with polypropylene macrofibers can reduce the fragility and shrinkage of silica fume mixtures. Here, we investigated the effect silica fumes and aggregates have on enhancing high-performance concrete with polypropylene macrofibers. Three dosages of polypropylene macrofibers were evaluated $(0.39,0.63$, and $0.79 \%$ volume fraction), including silica fume $(0.0$ and $7.0 \%$ water-cement), for two types of coarse aggregate (limestone and river gravel), with two maximum nominal sizes of coarse aggregate. In total, 96 concrete specimens were subjected to compression and bending tests to evaluate the effect of adding fiber, silica fume, and different aggregate types. The results showed a resistance to compression between 36 and $71 \mathrm{MPa}$, and that to flexural strengths of 3.6 to $5.8 \mathrm{MPa}$, which indicates high-performance concrete. The work shows that it is possible to achieve high-strength concrete with $55 \mathrm{~mm}$ polypropylene macrofibers combined with silica fumes and natural aggregates of both the limestone and calcareous types, which is beneficial for the local production of high-performance concrete.
\end{abstract}

Keywords: Fiber-reinforced concrete; polypropylene macrofibers; silica fume; coarse aggregate Received: 09/12/2019

Accepted: 26/04/2021

Available online: 31/12/2021.

* Research article

a M.Sc. and Specialist in Land Road Engineering. Universidad de Cartagena, Cartagena, Colombia. E-mail: rtorreso@unicartagena.edu.co ORCID: http://orcid.org/0000-0003-4215-1037

b Ph.D. in Engineering. M.Sc. in Environmental Engineering. Universidad de Cartagena, Cartagena, Colombia. E-mail: equinonesb@unicartagena.edu.co ORCID: http://orcid.org/ 0000-0002-2833-8455

c M.Sc. in Environmental Engineering. Universidad de Cartagena, Cartagena, Colombia. E-mail: ctejadat@ unicartagena.edu.co ORCID: http://orcid.org/ 0000-0002-2323-1544

d M.Sc. in Materials Engineering. Universidad de Cartagena, Cartagena, Colombia. E-mail: ygarciad1@unicartagena.edu.co ORCID: http://orcid.org/ 0000-0002-1078-9928

e B.Sc. in Civil Engineering. Universidad de Cartagena, Cartagena, Colombia. E-mail: icabarcast1@unicartagena.edu.co ORCID: http://orcid.org/ 0000-0001-7903-5692 
How to cite: R. Torres-Ortega, E. Quiñonez-Bolaños, C. Tejada-Tovar, Y. García-Díaz, and I. Cabarcas-Torres, "Highstrength Concrete with Natural Aggregates, Silica Fume, and Polypropylene Macrofibers", Cien.Ing.Neogranadina, vol. 31, no. 2, pp. 27-40, Dec. 2021.

\section{Hormigón de alta resistencia con agregados naturales, humo de sílice y macrofibras de polipropileno}

Resumen: el uso de hormigón con macrofibras de polipropileno puede reducir la fragilidad y la contracción de las mezclas de humo de sílice. En el presente estudio, se investiga el efecto que tienen los humos de sílice y los agregados en la mejora del hormigón de alto desempeño con macrofibras de polipropileno. Se evaluaron tres dosis de macrofibras de polipropileno (fracción de volumen de $0.39 \%, 0.63 \%$ y $0.79 \%$ ), incluido el humo de sílice (0.0 \% y $7.0 \%$ de agua-cemento), para dos tipos de agregado grueso (piedra caliza y grava de río) con dos tamaños nominales máximos. En total, 96 probetas de concreto se sometieron a pruebas de compresión y flexión para evaluar el efecto de la adición de fibra, humo de sílice y diferentes tipos de agregados. Los resultados mostraron una resistencia a la compresión entre $36 \mathrm{MPa}$ y $71 \mathrm{MPa}$, y una resistencia a la flexión de $3.6 \mathrm{MPa}$ a $5.8 \mathrm{MPa}$, lo que indica un concreto de alto desempeño. El trabajo demuestra que es posible conseguir un hormigón de alta resistencia con macrofibras de polipropileno de $55 \mathrm{~mm}$ combinadas con humos de sílice y agregados naturales tanto de tipo calizo como calcáreo, lo que resulta beneficioso para la producción local de hormigón de alto desempeño.

Palabras clave: hormigón reforzado con fibra; macrofibras de polipropileno; humo de sílice; agregado grueso 


\section{Introduction}

The achievement of transforming good highresistance concrete for compression and flexion is fundamental for the construction and stability of high-rise buildings and the design of coastal structures, pavements, tunnels, and large-dimension road bridges [1]. High-strength concrete is possible owing to the existence of new types of cement [2], superplasticizer additives [3], the use of fine materials such as silica fume (sF), ground quartz, fly ash, and the development of new types of structural fibers [4]. Much published research [5]-[11] has enhanced the performance of high-strength concrete by combining different types of materials, among which we can find the combination of SF with macro synthetic polypropylene fibers (PF) [12], [13], which achieves better ductile concrete behaviors and compressive strengths higher than $40 \mathrm{MPa}$. The inclusion of $\mathrm{PF}$ and $\mathrm{SF}$ in concrete offers a decrease in the utilization of continuous steel reinforcement bars to withstand traction and shear forces, occasionally providing a better degree of ductility (or energy absorption).

On the other hand, SF is an addition that augments the adhesion capacity in polypropylene fibers by a factor of 3 to 7 , as well as the density of the interfacial area and, because of its pozzolanic activity and its filler effect, increases compressive strength $\left(f_{c}\right)$ by more than $100 \%$. The combined effect of $P F$ microfibers and $s F$ can increase $f_{c}$, cracking at early ages, permeability, and reducing carbonation depths [9] . As for steel fibers, it has been found that the resistance to compression and flexural strength $\left(\mathrm{f}_{\mathrm{f}}\right)$ can increase by 85.5 and $64.9 \%$, respectively. When only silica fume and fibers are added, the increase is $113-117 \%$ for compression and $85-136 \%$ for flexural strength. Therefore, concretes produced with sF additions can be more resistant than those containing only SF [14]. Synthetic fiber increased the failure load of reinforced concrete beams and improved the serviceability by reducing the number and width of cracks [15].

Furthermore, the enhancements can be attributed to the internal confinement/cracks arresting mechanism and toughness [16]. For this reason,
PF has become popular in constructing pavement, prefabricated elements, and projected concrete mine tunnels [17]. Cohesion in the microcracking concrete reinforced with PF area depends not only on the cohesion but also on the bridge tension of the fiber. Furthermore, the constitutive features of the concrete reinforced with PF are closely related to the nature of the concrete substrate [18].

However, despite such results, more studies are required to control and optimize the increased demand for water in concrete due to the use of silica fume [14] or fly ash [19], [20]. The PF alters the microstructure in terms of hydration, causing condensation on the concrete's microstructure [21]. Then, the use of SF must be taken into account because it accelerates the hydration process [22]. Ductility plays an essential role in the increased use of high-resistance concrete and its application areas, but SF also makes the concrete develop a more brittle structure due to the high resistance it provides.

Therefore, improving this characteristic is a significant problem for high-strength concrete when adding SF because concrete's ductility can be heightened through the use of sF in concrete; this depends on bonding with a synthetic fiber in a concrete matrix [14], [23], [24].

During the development of high-strength concrete, different pFs have been previously used. Nevertheless, microfibers or short fibers $(<3 \mathrm{~cm})$ are used in many studies, which, despite improving shrinkage, provide little flexural strength and influence coarse aggregates to manufacture highstrength concrete. As a result, the effect of the size of $P F$ fibers is a factor that requires further study. Upon observing the impact and mechanical strength of concrete mixtures achieved with short fibers of polypropylene and silica fume, strength properties improve, particularly the concrete's impact resistance [7], which reaches an increase in resistance above $10 \%$ adding fibers [6]. Beyond adding the superplasticizer, it has been found that better control of workability, drop, flow dispersion, and flow rate decreased (along with sF) when PF volume or length increased [25]. This aspect can be 
controlled when adding SF because the small size of microsilica particles improves the packing and contact surface [26].

Due to all of the above, this paper contributes to the search for an optimal high-performance concrete design using local sources. Herein, we provide an experimental and theoretical analysis. We examined the mechanical behavior and workability of the combined use of silica fume and long polypropylene macrofibers, along with local natural limestone and river gravel aggregates commonly used in the Colombia Caribbean cost used at two maximum nominal sizes.

\section{Materials and methods}

The fiber used in this study was monofilament polypropylene. It had a length of $55 \mathrm{~mm}$, a flexural strength of $524 \mathrm{MPa}$, and a recommended use at 2 to $5 \mathrm{~kg} / \mathrm{m}^{3}$. Coarse aggregates were one type of limestone (L), which originated from quarry exploitation, and another from siliceous river gravel (RG) fractured origin taken from old stormwater channels in the north of Bolívar, Colombia. The characteristics of the aggregates are shown in Table 1 and Fig. 1.

Fig. 1. Coarse aggregates.

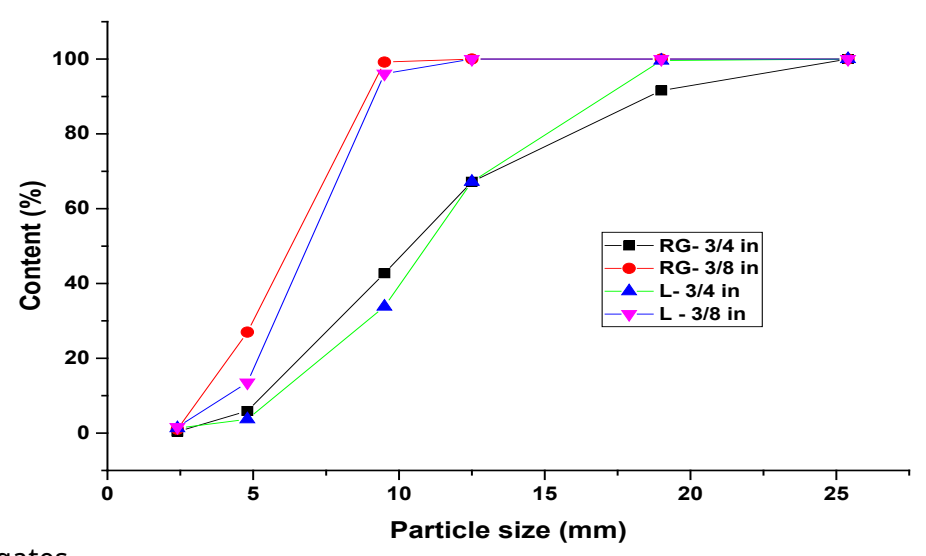

Source: Own elaboration

The sand used was of the siliceous type, with a $2.51 \mathrm{~g} / \mathrm{cm}^{3}$ dry density, fineness modulus of 3.28 , absorption at $2.35 \%$, and an evaporable moisture content of $3.08 \%$. The cement was a high-strength type (or High Early Strength (HE) type as per AsтM C1157) [27], because, in Colombia, this cement is frequently recommended and used in all significant urban infrastructure works. The sF used had a $\mathrm{SiO}_{2}$ content greater than $95 \%$, a specific surface higher than 30 $\mathrm{m}^{2} / \mathrm{g}$, and 3 to $5 \%$ water content. The type F superplasticizer additive based on polycarboxylates and type D retardant setting additive had proportions below $1 \%$.

Table 1. Characteristics of coarse aggregates

\begin{tabular}{lll} 
Parameter & Limestone & River gravel \\
\hline Resistance to degradation: Los Angeles testing machine (\%) & 28.24 & 12.48 \\
\hline Clay lumps (\%) & 0.84 & 0.71 \\
\hline Absorption & 4.5 & 1.00 \\
\hline Uniformity coefficient & $1.58-2.17$ & $1.8-2.13$ \\
\hline Dry density & 2266.79 & 2462.66 \\
\hline Saturation density & 2368.80 & 2487.29 \\
\hline Apparent density & 2425.00 & 2525.00 \\
\hline
\end{tabular}




\section{Method}

The mixtures were made with a $7 \%$ wc (water-cement) dosage of sF at a $0.47 \mathrm{wb}$ ratio. For each aggregate, two gradations were used: $3 / 8$ in and $3 / 4$ in the fiber volume ranged from $0.0,0.39,0.63$, and 0.79 in $\% \mathrm{~V}_{\mathrm{f}}$. The mixture design is shown in Table 2. Three cylindrical test tubes with a diameter of 100 $\mathrm{mm}$ and a height of $200 \mathrm{~mm}$ were used to evaluate the compressive strength under the AsTM C39M standard [28] for each fiber dosage and aggregate. Then, the procedures were repeated for mixtures with $7.0 \%$ wc of sF. For $f_{f}$, the same combinations were made in prismatic specimens with dimensions of $50 \times 150 \times 150 \mathrm{~mm}^{3}$ following the ASTM C782 standard methodology [29]. A total number of 48 compressions and 48 flexural strength tests were performed after seven days when the cure was at $100 \%$ humidity. The sample preparation procedure and curing were made according to the ASTM C192/C192M-18 [30]. The mixtures were compacted in three layers with 25 strokes, taking the slump value as an indicator of workability following the AsTM C143 test methodology [31].

Table 2. Mix proportions

\begin{tabular}{lllllllll} 
Mix & C & W & S & SF & CA & F & AT-F & AT-D \\
\hline L & 448 & 210 & 660 & 0 & 930 & $0 ; 0.39 ; 0.63 ; 0.79$ & 0.8 & 0.4 \\
\hline RG & 448 & 210 & 660 & 0 & 930 & $0 ; 0.39 ; 0.63 ; 0.79$ & 0.8 & 0.4 \\
\hline L+SF & 448 & 226 & 660 & 31 & 930 & $0 ; 0.39 ; 0.63 ; 0.79$ & 0.6 & 0.4 \\
\hline RG+SF & 448 & 226 & 660 & 31 & 930 & $0 ; 0.39 ; 0.63 ; 0.79$ & 0.6 & 0.4 \\
\hline
\end{tabular}

${ }^{\star} \mathrm{C}$ : cement $\left(\mathrm{Kg} / \mathrm{m}^{3}\right)$; w: water $\left(\mathrm{Kg} / \mathrm{m}^{3}\right)$, s: sand $\left(\mathrm{Kg} / \mathrm{m}^{3}\right)$; CA: coarse aggregate $\left(\mathrm{Kg} / \mathrm{m}^{3}\right)$, F: fibers $\left(\% \mathrm{~V}_{\mathrm{f}}\right)$, AT-F: admixture type F (\%WC), and AT-D: admixture type D (\%wC)

Source: Own elaboration

\section{Results and Discussion}

\section{Workability}

The workability of the concrete was evaluated according to the settlement or slump value (Fig. 2).

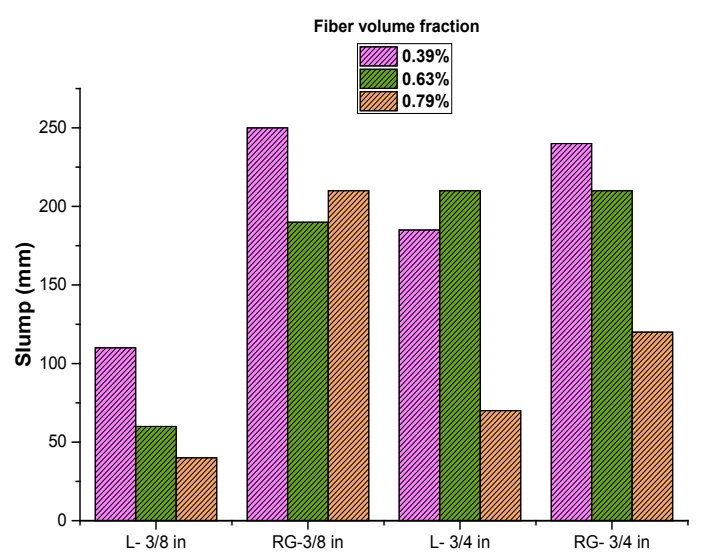

(a)

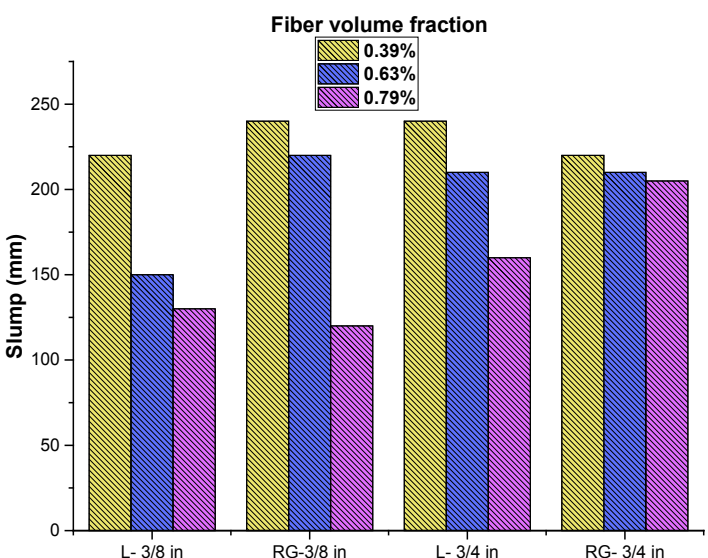

(b)

Fig. 2. Mixture settlement with different fiber dosages: (a) without SF and (b) with SF.

Source: Own elaboration 
As shown in Fig. 2, the mixture settlement was found to be within a range of 115 to $240 \mathrm{~mm}$, thus indicating high workability, which is typical for the use of high-strength concrete. In the first mixture made with $9 \mathrm{~mm} \boldsymbol{L}$ aggregate without SF, slumps below $100 \mathrm{~mm}$ were obtained. As such, the superplasticizer dosage increased, thus achieving a slump value greater than $100 \mathrm{~mm}$ in all mixtures. When the correction was applied on average, the slump value for the $3 / 8$ in limestone aggregate (L) was $118 \mathrm{~mm}$ and, for the size of $19.0 \mathrm{~mm}$, it was $179.1 \mathrm{~mm}$. However, for the $3 / 8$ in siliceous aggregate (RG), the average slump was $204.1 \mathrm{~mm}$, and for the size of $3 / 4$ in, it was 200.8 $\mathrm{mm}$. In cases where the limestone-type aggregate was used, the workability of the concrete mixture was more excellent when river gravel was used (Fig. 2a). As the maximum nominal size of coarse L aggregates increased, the workability with polymeric fibers improved, reducing the superplasticizer. The effect of coarse aggregates on workability is shown in Fig. 2b, increasing a slump between 10 and $20 \%$ when the maximum aggregate size increased from $3 / 8$ to $3 / 4$ during the maximum fiber dosage. In the L-type aggregate, a $0.2 \%$ higher superplasticizer dosage was applied to the siliceous type to maintain high slump levels, allowing for a similar degree of workability in the two aggregates. The concrete mix had more excellent workability for the $3 / 8$ in coarse siliceous aggregate (RG). This result is possible because such an aggregate is not fractured, providing it with lower surface roughness and improving the concrete's rheological characteristics [32].

Due to its hindrance for deformation and matrix movement, aggregate fibers decreased the workability of both concrete or mortar produced and increased the demand for water and cement paste [25]. The fibers' dispersion and surface coverage are significant for maintaining isotropic conditions and ensuring the highest anchorage of the fiber. Fig. 2 shows that, despite using a superplasticizer, the slump of the mixtures was not constant and the workability hinged on the mixture's fiber content. On the other hand, the workability decreased proportionally with the coarse aggregate size because, when the diameter was reduced, there was a greater surface area [33], [34].

\section{Compressive Strength}

The results from the tests showed a compressive strength between 36 and $71 \mathrm{MPa}$, indicating a high-strength concrete. The lowest compressive strength values were achieved when both $3 / 8$ in and $19.0 \mathrm{~mm}$ river gravel aggregates were used (Fig. 3) without silica fume, which indicated that the material was conventional concrete with cement.

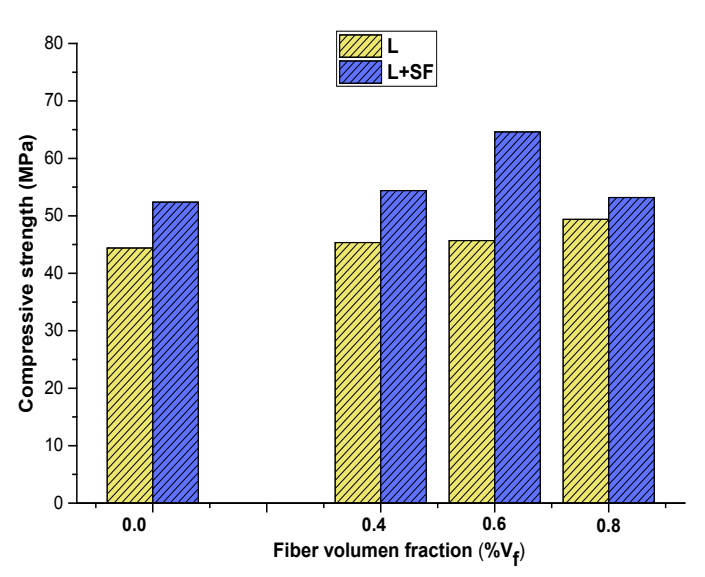

(a)

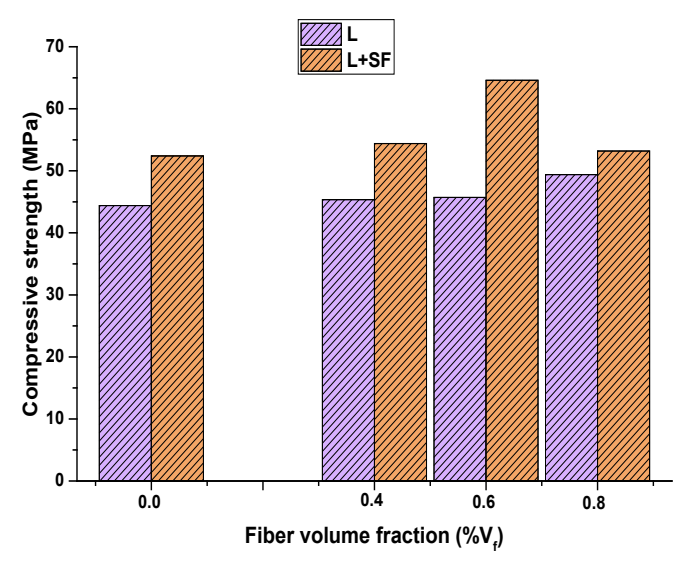

(b)

Fig. 3. Compressive strengths adding SF, different fiber dosages, and L aggregate sizes: (a) 3/8 in and (b) 3/4 in. Source: Own elaboration 
Fig. 3 shows the increase in $f_{c}$ when silica fume was added to the two aggregates. When a smaller maximum nominal size aggregate was used, there was a variation of the increase in $f_{c}$ between 5-10 $\mathrm{MPa}$. However, when a larger aggregate was used, the variation reached $20 \mathrm{MPa}$. The fiber used displayed an $f_{c}$ enhancement under a specific dosage and then declined. The increase in $\% \mathrm{~V}_{\mathrm{f}}$ saturated the concrete matrix, generating agglomerates similar to the $\mathrm{L}+\mathrm{SF}$ mixture with $0.79 \% \mathrm{~V}_{\mathrm{f}}$.

Fig. 3b shows a dramatic drop in resistance for the said mixture. Such a drop was ascribed to the shortage of particles smaller than the maximum nominal size in the 3/4 type L aggregate (Fig. 2). Moreover, the 3/4 in RG type aggregate had more diverse particle sizes with no agglomerations appearing, so its resistance maintained a behavior in line with the other results. Similar behaviors were found in previous research. Hasan et al. [35] found a 4 to $7 \%$ increase in compressive strength using $40 \mathrm{~mm}$ long PF without adding sF. Toutanji found an increase in $\mathrm{f}_{\mathrm{c}}$ with $0.3 \% \mathrm{~V}_{\mathrm{f}}$ and a decline when using $0.5 \% \mathrm{~V}_{\mathrm{f}}$ [11]. A greater fiber volume contributed a higher volume of incorporated air, and

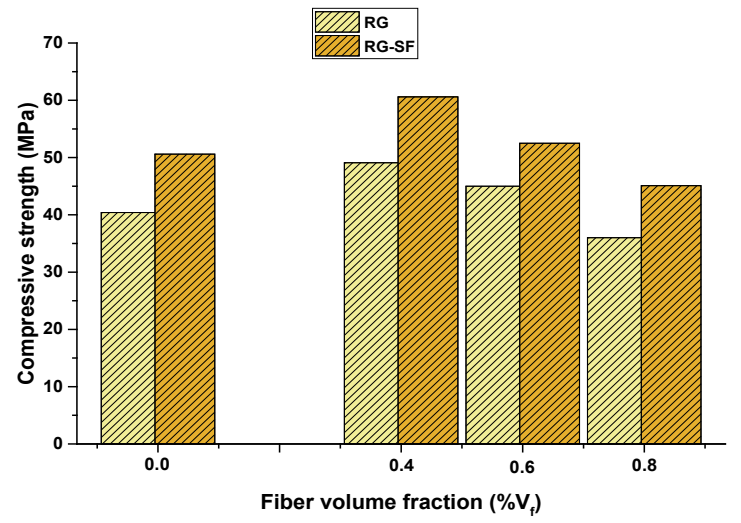

(a) possibly, for high fiber percentages, the amount of extra air could lead to the formation of microcracks and a decrease in unit weight [36].

The enhanced compressive strength of the fiber-reinforced concrete (Fig. 4) was attributed to the ability of the fibers to restrict and delay the spreading of cracks and reduce the degree of stress concentration within the crack [37]. PP microfibers performed a bridging function in microcracks more efficiently, while PP macrofibers effectively participated in the conveyance of efforts when the maximum load point was reached. Moreover, close to the time of failure, polypropylene macrofibers increased ductility and prevented the propagation of cracks [12]. Previous research showed that without the silica fume, fiber raised the $f_{c}$ to an optimal point [35], while the addition of silica fume facilitated the dispersion of fibers and provided additional resistance [7]. In previous studies, PF improved the shrinkage of the concrete allowing for three-dimensional reinforcement on a small scale [21]. In this manner, the packing effect that enhanced compressive strength prolonged the final state prior to a compression failure.

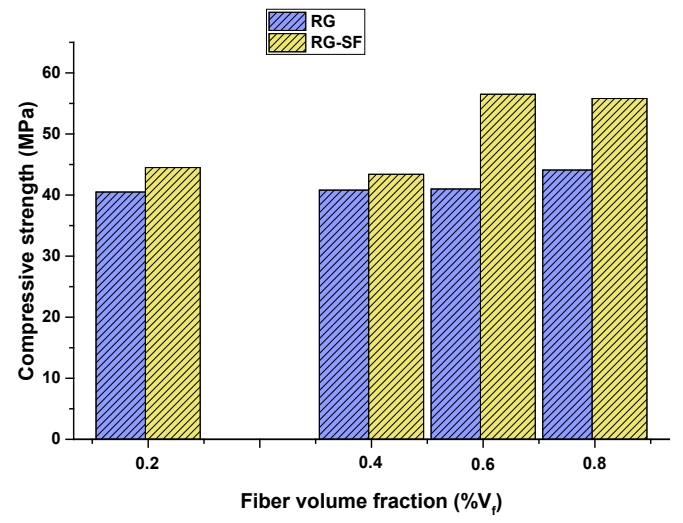

(b)

Fig. 4. Compressive strengths adding SF for different fiber dosages and RG aggregate sizes: (a) 3/8 in and (b) 3/4 in. Source: Own elaboration 


\section{Flexural Strength}

Fig. 5 shows an increase in $\mathrm{f}_{\mathrm{f}}$ induced by adding SF to the mixture. The values were significant for the limestone aggregate. The dosage of $0.39 \% \mathrm{~V}_{\mathrm{f}} \mathrm{did}$ not significantly impact the resistance variation, whereas the $0.79 \% \mathrm{~V}_{\mathrm{f}}$ dosage exceeded the pattern sample. In the case of the RG aggregate, the $f_{f}$ diminished with dosages of 0.39 and $0.63 \% \mathrm{~V}_{\mathrm{f}}$. PF improved the bridging behavior of the fibers within the cracks. SF as an addition in concrete resulted in a better transfer of tensile stress to the fiber [9].

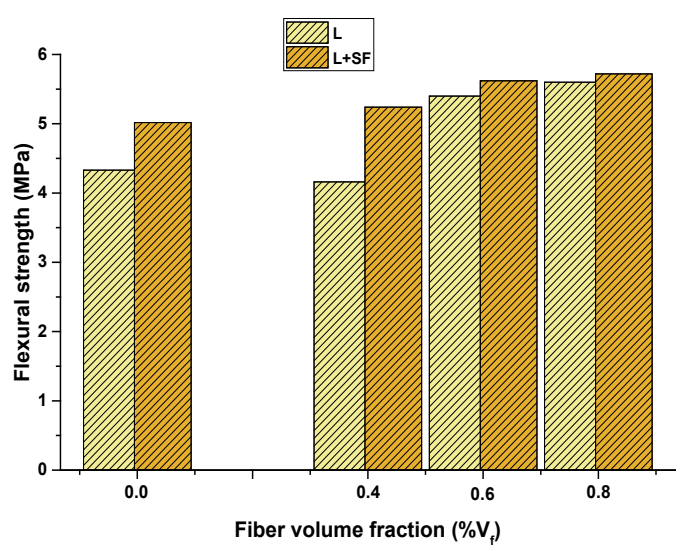

(a)

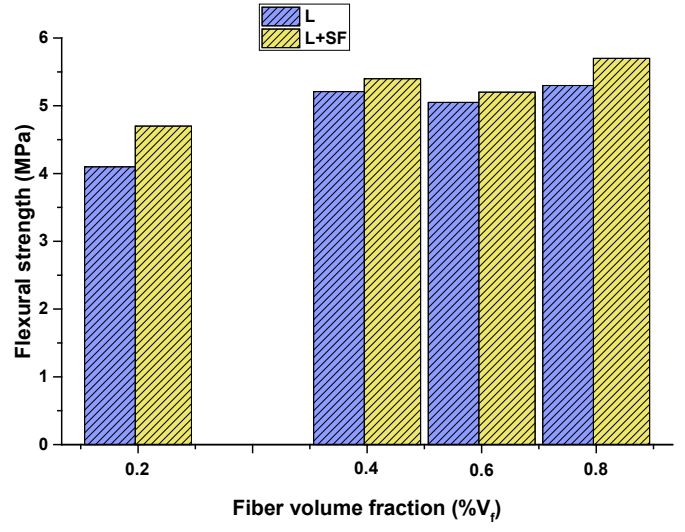

(b)

Fig. 5. Variation of flexural strength for limestone aggregate at seven days: (a) 3/8 in aggregate; (b). 3/4 in aggregate.

Source: Own elaboration

Fig. 6 shows that the increased behavior in $\mathrm{f}_{\mathrm{f}}$ was maintained by adding sF to the mixture. The values were more significant for the limestone aggregate, and all the dosages increased above the pattern sample. Furthermore, the $f_{f}$ values for the $3 / 4$ in aggregates were generally lower than those for the $3 / 8$ in samples, indicating that there may be a reduction in $\mathrm{f}_{\mathrm{f}}$ from the increase in aggregate size.

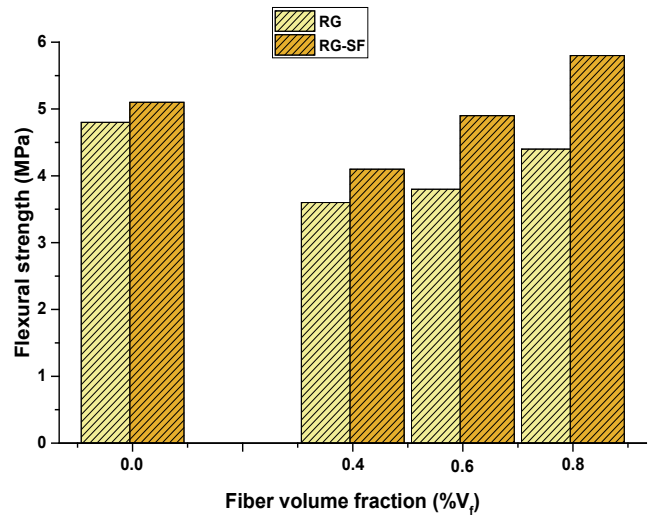

(a)

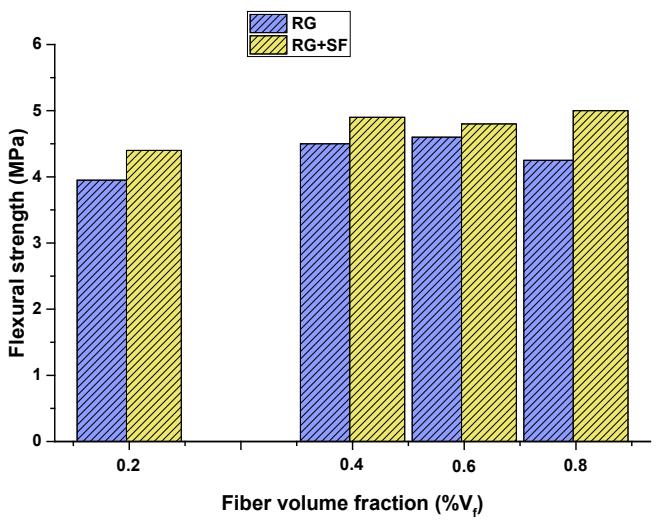

(b)

Fig. 6. Flexural strength for river gravel aggregate: a. 3/8 in; b. 3/4 in.

Source: Own elaboration 
Using siliceous aggregates, their high rigidity and smooth surface may lead to a weaker interfacial transition zone than crushed aggregates, affecting fracture mechanisms due to the "incompatibility" of river gravel deformation with the surrounding cement paste. Consequently, when integrated into a cement-based matrix, they can significantly affect the rheology and mechanical performance of self-compacting concrete and fiber-reinforced concrete matrices. Such aggregates reduced deformation capacity in the matrix, which resulted in a more fragile mechanical response under compression stress and flexural strength [32]. In the case of microfibers, PF exerts a bridging effect on both sides of the concrete's fracture section, specifically when the matrix breaks. The PF that bonded the microcrack tensed when the crack developed and supported the tensile stress transferred from the fracture section.
At the same time, the concentration of stress in the area of the fracture became weak. This effect postponed the development of cracking damage and improved the ductility of the stress from silica fume. As a result, $\mathrm{f}_{\mathrm{f}}$ improved with PF [10]. As for macrofibers, the effect was expected to work similarly but with a more incredible crack opening.

Fig. 7 shows the maximum increases for each aggregate type and size regarding the sample without silica fume and fibers. This figure shows that, on an individual basis, $S F$ and $P F$ raised the $f_{c}$ and $f_{f}$, but the combined use heightened the value even above the sum of the increases each addition brings. For both aggregates, there was a similar increase in $\mathrm{f}_{\mathrm{c}}$ by individually adding fiber and silica fumes when the coarse aggregate had a size of $3 / 8$ in (Fig. $7 a)$. When the size of the RG aggregate was raised, the increase in $f_{c}$ decreased.
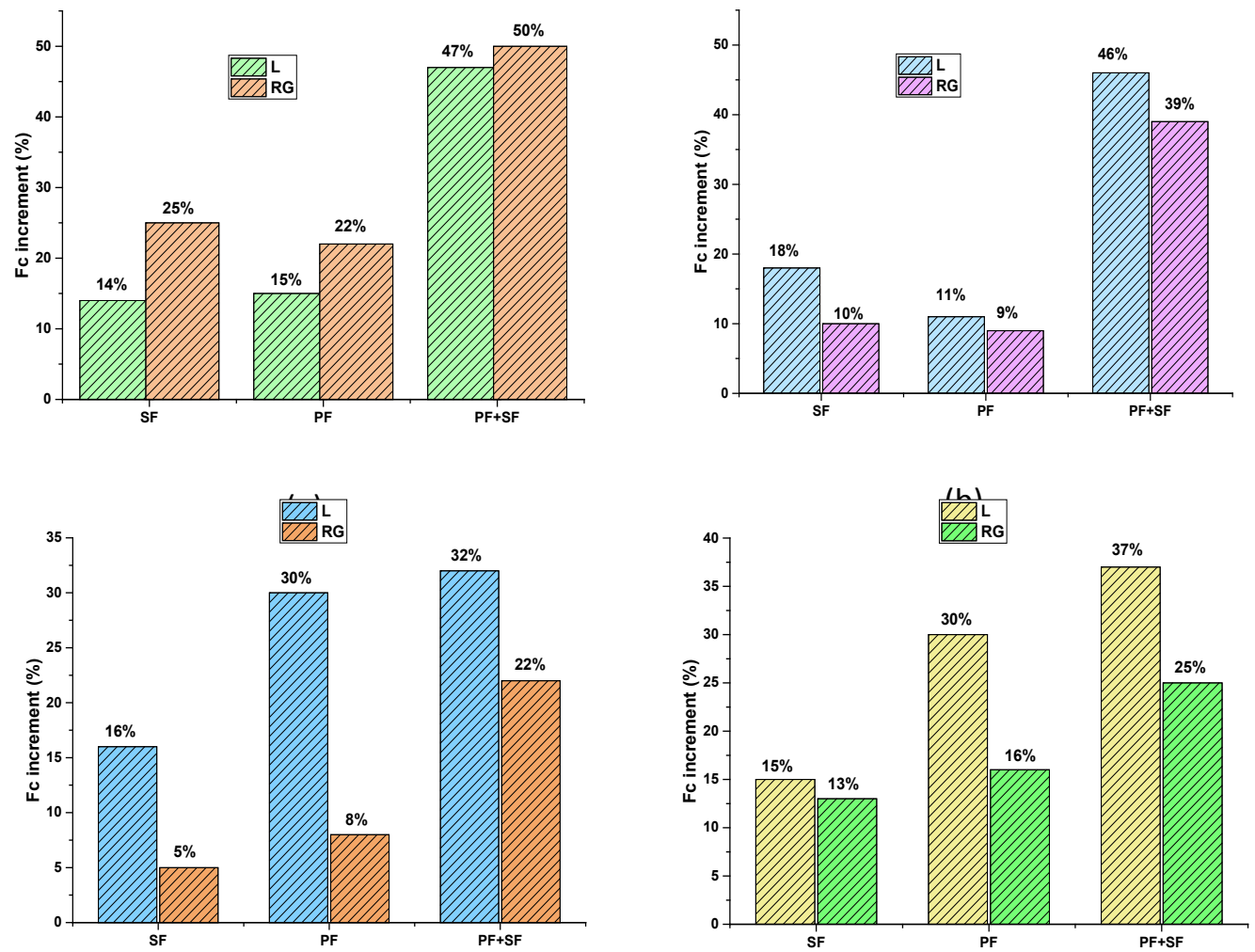

(c)

(d)

Fig. 7. Increase in resistance when adding SF, with an optimum dose of $\mathrm{PF}$, and when combining the optimum $\mathrm{PF}$ and SF for each type of aggregate with maximum size ( $a$ and c) for 3/8 in (b and d) and 3/4 in.

Source: Own elaboration 
In the case of the flexural strength, the combined use of both increased said value, but it did not rise above the sum of the increases that each addition brought. It should also be noted that fiber had a more significant effect on $\mathrm{f}_{\mathrm{f}}$ than silica fume. Similar to other research with polypropylene macrofibers, flexural strength and compression results showed that PF, when combined with SF, increases adhesion strength and extraction energy [22]. In a study with microscopic images, Park and Lee [13] observed that the synthetic macro fiber within silica fume influenced the number and extension of scratches and tears after a pull-out test, which was attributed to the friction during the extraction of the fiber. In addition, surface abrasion and the tearing of polypropylene macrofibers showed a trend similar to the bond strength and interface strength. Therefore, silica fume improved cement-based compounds' bond strength and interfaced strength by increasing friction during polypropylene macrofiber extraction. This quality allowed for the accomplishment of higher flexural strength loads.

In research projects where the concrete's $f_{c}$ and $\mathrm{f}_{\mathrm{f}}$ were tested, it was possible to observe an increase in such parameters [36]. However, to compare the maximum effect of each addition to the concrete's final performance, the individual and combined fibers and sF were first evaluated. Fig. 7 shows a maximum increase of $f_{c}$ and $f_{f}$ through the RG + SF combination with a maximum size of $3 / 8$ in and increase values of 50 and $22.0 \%$. However, as shown in Fig. 3, the maximum strength when adding fiber and silica fume was higher for aggregate $\mathrm{L}$ in all cases, which means that the addition of SF and PF improved the compatibility of the mixture much more than when RG-type aggregates were used.

Furthermore, the Type L aggregates achieved a higher performance with SF and fibers due to the very nature of the material, which was reflected in a better performance in the pattern samples without fiber when aggregate $\mathrm{L}$ was used. The effect of better anchorage in fiber with sF allowed it to better use its bridging capacity over a surface area where it made more excellent contact with the paste. On the other hand, the potential microcracks derived from the higher rigidity of the mixture due to the inclusion of silica fume were reduced when including PF; therefore, the mixture was more compact, and the joint use of the two materials generated greater mechanical capacity compared to what was provided individually.

Table 3 shows a comparison of the data obtained by Fallah and Nematzadeh [12], who took the gradation most similar to the material (i.e., limestone aggregate with ranges between $2.2 \mathrm{~mm}$ and $3 / 8$ in (L 3/8 in)). Therefore, the resistances corresponding to this material were taken. The macrofibers used had a $39 \mathrm{~mm}$ and $0.78 \mathrm{~mm}$ diameter, which provided an aspect ratio of 50 . For the present study, an aspect ratio of 91.7 was taken. In previous works, the straight fibers with the highest aspect ratio were more effective for improving the performance in flexural strength [38] and compression [14].

Table 3. Comparisons with the present work.

Fallah and Nematzadeh [12]

\begin{tabular}{|c|c|c|c|c|c|c|c|c|c|}
\hline Mix & $\begin{array}{l}\mathrm{f}_{c} \\
\operatorname{MPa}\left({ }^{*}\right)\end{array}$ & $\begin{array}{l}C v^{* *} \\
(\%)\end{array}$ & $\begin{array}{l}\text { SPA } \\
\text { (\% wb) }\end{array}$ & $\begin{array}{l}\text { Slump } \\
(\mathrm{mm})\end{array}$ & Mix & $\begin{array}{l}\mathrm{f}_{\mathrm{c}} \\
\mathrm{MPa}\left({ }^{*}\right)\end{array}$ & $\begin{array}{l}\mathrm{Cv}^{* *} \\
(\%)\end{array}$ & $\begin{array}{l}\text { SPA } \\
(\% \\
\text { wb) }\end{array}$ & $\begin{array}{l}\text { Slump } \\
(\mathrm{mm})\end{array}$ \\
\hline \multicolumn{10}{|c|}{ Mix with fibers } \\
\hline Plain & $58.8(-)$ & 3.2 & 0.6 & 170 & $\begin{array}{l}\mathrm{SF} 0-\mathrm{FP} 0-3 / 8 \\
\text { in }\end{array}$ & $48(-)$ & 1.2 & 0.8 & 240 \\
\hline MP0.25 & $63.5(8)$ & 3.6 & 0.6 & 170 & $\begin{array}{l}\text { SF0- } \\
\mathrm{FP} 0.39-3 / 8 \text { in }\end{array}$ & 54.49 (12.7) & 6.1 & 0.8 & 240 \\
\hline MP0.5 & $61.3(4.2)$ & 1.7 & 0.6 & 170 & $\begin{array}{l}\mathrm{SF} 0- \\
\mathrm{FP} 0.63-3 / 8 \text { in }\end{array}$ & $55.67(15.1)$ & 3.0 & 0.8 & 240 \\
\hline MP0.75 & $60.7(3.3)$ & 6.6 & 0.6 & 170 & $\begin{array}{l}\text { SFO- } \\
\text { FP0.79-3/8 in }\end{array}$ & $55.64(15.1)$ & 5.7 & 0.8 & 210 \\
\hline
\end{tabular}




\begin{tabular}{|c|c|c|c|c|c|c|c|c|c|}
\hline MP1.25 & $56.4(-4.2)$ & 7.9 & 0.6 & 170 & & & & & \\
\hline \multicolumn{10}{|l|}{ Mix with SF } \\
\hline SF10 & $81.1(37.9)$ & 0.8 & 0.65 & 110 & \multirow{2}{*}{$\begin{array}{l}\text { SF7-FP0-3/8 } \\
\text { in }\end{array}$} & \multirow{2}{*}{$55.26(14.3)$} & \multirow{2}{*}{4.5} & \multirow{2}{*}{0.6} & \multirow{2}{*}{90} \\
\hline SF12 & $83.0(41.1)$ & 5.4 & 0.65 & 70 & & & & & \\
\hline \multicolumn{10}{|c|}{ Mix with SF and fibers } \\
\hline \multirow{3}{*}{ MP1.25sF10 } & \multirow{3}{*}{$70.7(20.1)$} & \multirow{3}{*}{3} & \multirow{3}{*}{0.93} & \multirow{3}{*}{110} & $\begin{array}{l}\text { SF7- } \\
\text { FP0.79-3/8 in }\end{array}$ & $71.1(47.11)$ & 2.4 & 0.8 & 130 \\
\hline & & & & & $\begin{array}{l}\text { SF7- } \\
\text { FP0.39-3/8 in }\end{array}$ & $60.01(24.16)$ & 2.4 & 0.8 & 220 \\
\hline & & & & & $\begin{array}{l}\text { SF7- } \\
\text { FP0.63-3/8 in }\end{array}$ & $68.87(42.49)$ & 4.9 & 0.8 & 150 \\
\hline
\end{tabular}

${ }^{\star} \%$ improvement of strength. ${ }^{*}$ Coefficient of variation.

Source: Adapted from [12]

The additive percentage was higher in the mixture $(0.8 \% \mathrm{wc})$ than in the previous work $(0.6)$, which provided the mixture with a better level of workability; however, in the ternary mixture (MP1.25sF10), the dosage increased (0.93\%) improving the consistency, whereas the incorporated air decreased, and the resistance was raised to a value similar to the present study (70.7-71.1 $\mathrm{MPa})$. The previous investigation did not use the optimal fiber dosage $\left(0.5 \% \mathrm{~V}_{\mathrm{f}}\right)$, but combined sF and PF were higher $\left(1.25 \% V_{f}\right)$. Such higher dosages initially reduced its resistance by $4.2 \%$; therefore, it was assumed that the authors could have obtained an $f_{c}$ increase percentage higher than what was registered (20.1\%), mainly when the optimal dosage of polypropylene macrofibre was used. The proportion of the coarse aggregate concerning the cement used in this study (2) was 30\% greater than the one used previously (1.7), which might explain the lower $f_{c}$ values when sF was not incorporated. As we noted, the finer the granulometry, the greater the density and final strength of the concrete. However, there were higher percentages of $f_{c}$ when fibers were incorporated, which may be because their sand was a type of crushed gravel with minimum diameters of $0.15 \mathrm{~mm}$. However, for this study, natural silica sand with minimum diameters of $0.055 \mathrm{~mm}$ was used. Although the percentage of sand was low, the fineness provided the fiber with higher surface friction. In contrast to the previous work, there was a contribution of results in terms of the flexural strength, so it was not possible to compare such results; however, it has been highlighted that the results for flexural strength remained at values above $4 \mathrm{MPa}$, which allowed for a good balance with high compressive strengths.

\section{Conclusions}

High-strength concretes (with resistance to 40$71 \mathrm{MPa}$ compression and 3.6 to $5.8 \mathrm{MPa}$ flexion) made with natural river gravel or limestone type aggregates, with maximum nominal sizes of $3 / 8$ in, were achieved when adding silica fume and polypropylene macrofibers of $55 \mathrm{~mm}$. The concrete maintained its workability and showed good resistance to compression and flexural strength. The above represent useful features for constructing pavements, slabs, and beams for high-rise buildings. The workability of the mixture was directly decreased upon adding silica fume and decreased with the volume of fibers, a reduction in aggregate size, and irregular geometry. The river gravel type aggregate demanded less superplasticizer usage, while the coarse aggregate demanded more water consumption. However, the proper application of the plasticizer took the abovementioned variables 
into account, which enabled it to achieve a level of workability that ensured a slump above $100 \mathrm{~mm}$.

Moreover, concrete with polymer fibers had a variable $f_{c}$ and $f_{f}$ behavior that depended on fiber dosage, aggregate type, and granulometry. The optimal dosage for each type of aggregate was 0.63 $\mathrm{V}_{\mathrm{f}}$ for the RG type and $0.79 \% \mathrm{~V}_{\mathrm{f}}$ for the $\mathrm{L}$ type. Such an optimum dosage should be studied further to improve the performance and economy of the mixture. The incorporation of sF into the mixture improved resistance to compression, especially compared to flexural strength. However, both values were still higher than the individual effects of the additions when optimum polypropylene macrofiber dosages were used. The polypropylene macrofiber and silica fume resulted in a better performance when using coarse aggregates at a maximum nominal size of $3 / 8$ in than when using a maximum nominal size of $3 / 4 \mathrm{in}$. The limestone-type aggregates achieved higher resistance with SF and fibers due to the nature and shape of the material, which was reflected in higher $f_{c}$ and $f_{f}$ values. However, the addition of silica fume and fiber helped the RG-type aggregates to achieve even better resistance.

\section{Acknowledgments}

The authors would like to thank the Universidad de Cartagena for its laboratory usage, software assistance, and research time for the professors. Moreover, we would like to thank the Servicio Nacional de Aprendizaje (SENA) for its financial support.

\section{References}

[1] B. Price, High strength concrete. Woodhead Publishing Limited, 2003.

[2] F. Sorrentino, "Chemistry and engineering of the production process: State of the art," Cem. Concr. Res., vol. 41, no. 7, pp. 616-623, 2011, DoI: https://doi. org/10.1016/j.cemconres.2011.03.013.

[3] P.-C. Nkinamubanzi, S. Mantellato, and R. J. Flatt, "Superplasticizers in practice," Sci. Technol. Concr. Admixtures, pp. 353-377, Jan. 2016, Dor: https://doi. org/10.1016/B978-0-08-100693-1.00016-3.
[4] M. I. Khan, Y. M. Abbas, and G. Fares, "Review of high and ultrahigh performance cementitious composites incorporating various combinations of fibers and ultrafines," J. King Saud Univ. Eng. Sci., vol. 29, no. 4, pp. 339-347, 2017, Dor: https://doi.org/10.1016/j. jksues.2017.03.006.

[5] R. Reju and G. Jiji Jacob, "Investigations on the chemical durability properties of Ultra High Performance Fibre Reinforced Concrete," in 2012 Int. Conf. Green Technologies (ICGT), Dec. 2012, pp. 181-185, DoI: https://doi.org/10.1109/ICGT.2012.6477969.

[6] E. J. M. Castil and N. C. Tarranza, "Producing High Strength Hollow Core Reinforced Concrete Slab with Silica Fume and Polypropylene Fibers," Mater. Sci. Forum, vol. 866, no. 1, pp. 143-147, 2016, DoI: https:// doi.org/10.4028/www.scientific.net/MSF.866.143.

[7] M. Nili and V. Afroughsabet, "The effects of silica fume and polypropylene fibers on the impact resistance and mechanical properties of concrete," Constr. Build. Mater., vol. 24, pp. 927-933, 2009, DoI: https://doi.org/10.1016/j.conbuildmat.2009.11.025.

[8] M. M. Ahmed, "Study on durability properties of concrete using silica fume with addition of polypropylene fibre," vol. 3, no. 11, pp. 21-25, 2017.

[9] N. Flores Medina, G. Barluenga, and F. Hernández-Olivares, "Combined effect of Polypropylene fibers and Silica Fume to improve the durability of concrete with natural Pozzolans blended cement," Constr. Build. Mater., vol. 96, pp. 556-566, Oct. 2015, DoI: https://doi.org/10.1016/J.CONBUILDMAT.2015.08.050.

[10] H. W. Wang, "Effect of Polypropylene Fiber on Strength and Flexural Properties of Concrete Containing Silica Fume," Adv. Mater. Res., vol. 346, pp. 30-33, 2011, DOI: https://doi.org/10.4028/www.scientific. net/AMR.346.30.

[11] H. A. Toutanji, "Properties of polypropylene fiber reinforced silica fume expansive-cement concrete," Constr. Build. Mater., vol. 13, no. 4, pp. 171-177, Jun. 1999, DOI: https://doi.org/10.1016/S09500618(99)00027-6.

[12] S. Fallah and M. Nematzadeh, "Mechanical properties and durability of high-strength concrete containing macro-polymeric and polypropylene fibers with nano-silica and silica fume," Constr. Build. Mater., vol. 132, pp. 170-187, Feb. 2017, Dor: https://doi.org/10.1016/J.CONBUILDMAT.2016.11.100. 
[13] C.-G. Park and J.-W. Lee, "Effect of nanosilica and silica fume content on the bond properties of macrosynthetic fibre in cement-based composites," Mag. Concr. Res., vol. 65, no. 3, pp. 148-157, 2013, Dor: https://doi.org/10.1680/macr.12.00036.

[14] F. Kö Ksal, F. Altun, I. Yig it C, Y. ßa, and S. ßahin, "Combined effect of silica fume and steel fiber on the mechanical properties of high strength concretes," Constr. Build. Mater., vol. 22, no. 8, pp. 1874-1880, 2008, DoI: https://doi.org/10.1016/j.conbuildmat.2007.04.017.

[15] M. Ghahremannejad, M. Mahdavi, A. E. Saleh, S. Abhaee, and A. Abolmaali, "Experimental investigation and identification of single and multiple cracks in synthetic fiber concrete beams," Case Stud. Constr. Mater., vol. 9, p. e00182, 2018, Dor: https://doi.org/10.1016/j.cscm.2018.e00182.

[16] M. Alhassan, R. Al-Rousan, and A. Ababneh, "Flexural behavior of lightweight concrete beams encompassing various dosages of macro synthetic fibers and steel ratios," Case Stud. Constr. Mater., vol. 7, no. July, pp. 280-293, 2017, Dor: https://doi.org/10.1016/j. cscm.2017.09.004.

[17] S. Yin, R. Tuladhar, F. Shi, M. Combe, T. Collister, and N. Sivakugan, "Use of macro plastic fibres in concrete: A review," Constr. Build. Mater., vol. 93, pp. 180-188, Sep. 2015, DoI: https://doi.org/10.1016/J. CONBUILDMAT.2015.05.105.

[18] Z. Ming, "Double-K fracture analysis on polypropylene fiber reinforced concrete beams with standard three-point bending," in 2011 International Conference on Electric Technology and Civil Engineering (ICETCE), Apr. 2011, pp. 242-245, DoI: https://doi. org/10.1109/ICETCE.2011.5774387.

[19] O. Karahan and C. D. Atiş, “The durability properties of polypropylene fiber reinforced fly ash concrete," Mater. Des., vol. 32, no. 2, pp. 1044-1049, 2011, DoI: https://doi.org/10.1016/j.matdes.2010.07.011.

[20] V. C. Li and H. Stang, "Interface property characterization and strengthening mechanisms in fiber reinforced cement based composites," Adv. Cem. Based Mater., vol. 6, no. 1, pp. 1-20, Jun. 1997, Dor: https:// doi.org/10.1016/S1065-7355(97)90001-8.

[21] Z. Sun and Q. Xu, "Microscopic, physical and mechanical analysis of polypropylene fiber reinforced concrete," Mater. Sci. Eng. A, vol. 527, no. 1-2, pp. 198-204, 2009, Dor: https://doi.org/10.1016/j. msea.2009.07.056.
[22] D.-Y. Yoo and N. Banthia, "Mechanical properties of ultra-high-performance fiber-reinforced concrete: A review," Cem. Concr. Compos., vol. 73, pp. 267-280, Oct. 2016, Dor: https://doi.org/10.1016/J.CEMCONCOMP.2016.08.001.

[23] Y. Choi and R. L. Yuan, "Experimental relationship between splitting tensile strength and compressive strength of GFRC and PFRC," Cem. Concr. Res., vol. 35, no. 8, pp. 1587-1591, 2005, Dor: https://doi. org/10.1016/j.cemconres.2004.09.010.

[24] V. M. de Alencar Monteiro, L. R. Lima, and F. de Andrade Silva, "On the mechanical behavior of polypropylene, steel and hybrid fiber reinforced self-consolidating concrete," Constr. Build. Mater., vol. 188, pp. 280-291, 2018, Dor: https://doi.org/10.1016/j.conbuildmat.2018.08.103.

[25] L. G. Li, S. H. Chu, K. L. Zeng, J. Zhu, and A. K. H. Kwan, "Roles of water film thickness and fibre factor in workability of polypropylene fibre reinforced mortar," Cem. Concr. Compos., vol. 93, pp. 196204, 2018, DoI: https://doi.org/10.1016/j.cemconcomp.2018.07.014.

[26] P. Fidjestøl and R. Lewis, "Microsilica as an Addition," Lea's Chem. Cem. Concr., pp. 679-712, Jan. 1998, DoI: 10.1016/B978-075066256-7/50024-2.

[27] ASTM, ASTM C1157 / C1157M - 17 Standard Performance Specification for Hydraulic Cement. 2017.

[28] ASTM, ASTM C39 / C39M - 18 Standard Test Method for Compressive Strength of Cylindrical Concrete Specimens.

[29] ASTM, ASTM C78 - 02 Standard Test Method for Flexural Strength of Concrete (Using Simple Beam with Third-Point Loading). 2002.

[30] ASTM, ASTM C192 / C192M - 18 Standard Practice for Making and Curing Concrete Test Specimens in the Laboratory. 2018.

[31] ASTM, ASTM C143 / C143M - 15a Standard Test Method for Slump of Hydraulic-Cement Concrete. 2015.

[32] M. A. da Silva, M. Pepe, R. G. M. de Andrade, M. S. Pfeil, and R. D. Toledo Filho, "Rheological and mechanical behavior of High Strength Steel Fiber-River Gravel Self Compacting Concrete," Constr. Build. Mater., vol. 150, pp. 606-618, 2017, DoI: https://doi. org/10.1016/j.conbuildmat.2017.06.030.

[33] S. Chithra, S. R. R. Senthil Kumar, and K. Chinnaraju, "The effect of Colloidal Nano-silica on workability, mechanical and durability properties of High 
Performance Concrete with Copper slag as partial fine aggregate," Constr. Build. Mater., vol. 113, pp. 794-804, 2016, DOI: https://doi.org/10.1016/j.conbuildmat.2016.03.119.

[34] X. Liu, K. S. Chia, and M.-H. Zhang, "Water absorption, permeability, and resistance to chloride-ion penetration of lightweight aggregate concrete," Constr. Build. Mater., vol. 25, no. 1, pp. 335-343, Jan. 2011, DOI: https://doi.org/10.1016/J.CONBUILDMAT.2010.06.020.

[35] M. J. Hasan, M. Afroz, and H. M. I. Mahmud, "An Experimental Investigation on Mechanical Behavior of Macro Synthetic Fiber Reinforced Concrete," 2011.

[36] O. Gencel, C. Ozel, W. Brostow, and G. Martínez-Barrera, "Mechanical properties of self-compacting concrete reinforced with polypropylene fibres," $M a$ ter. Res. Innov., vol. 15, no. 3, pp. 216-225, 2011, DoI: https://doi.org/10.1179/143307511X13018917925900.

[37] H. Yan, W. Sun, and H. Chen, "The effect of silica fume and steel fiber on the dynamic mechanical performance of high-strength concrete," 1999.

[38] D.-Y. Yoo, S. Kim, G.-J. Park, J.-J. Park, and S.-W. Kim, "Effects of fiber shape, aspect ratio, and volume fraction on flexural behavior of ultra-high-performance fiber-reinforced cement composites," Compos. Struct., vol. 174, pp. 375-388, Aug. 2017, DoI: https:// doi.org/10.1016/J.COMPSTRUCT.2017.04.069. 